UDC 316.334.23

Liudmila VASILENKO

\title{
FRACTAL-SYNERGETIC APPROACH TO THE RESEARCH OF ENTREPRENEURSHIP IN THE NON-PROFIT ORGANIZATIONS
}

\begin{abstract}
We have applied the term "entrepreneurship" to the development of non-profit organizations working in the field of social and innovation activity, as a movement through the development of ideas towards creating new enterprises. We reviewed the promotion of social innovations on a methodological basis of sociosynergetics using cross-disciplinary and fractal-evolutionary approaches. The introduction of innovations is accompanied by the irreversibility expressed by the violation of symmetry between the past and the future (according to I. Prigozhin), and the research of innovations requires the introduction of the concept of an "event". Some events should have the ability to change the course of evolution. The criterion for evaluating the advancement of social innovation is the degree of its influence on the social system: the local nature of the impact - Auto-Poesies models; the emergence of a new parameter of order - Synergyintegrating models; the allocation of a new sub-system in the modernized old social system - Openness entrepreneurship models; the birth of a new social system. In managing innovation processes, it is important to choose such innovations that are in line with the trends in the development of the social system.
\end{abstract}

Keywords: social innovation, synergy, complexity, natural ordering, cross-disciplinary synthesis, fractal, values, openness, evolution, the models of entrepreneurship.

Introduction

Social innovation is considered as the introduction of the new into the quality of the "sociality" of the social system, which through the practical use of new ideas leads to a change in the structure of society or the growth of social capital. These changes are connected with social relations, culture, the direction of solving socially important problems. The mechanism of the spread of innovation is similar to the process of spreading the epidemic (self-organization, superfast mass distribution of the "infectious agent", a certain prototype of a social fractal). The relevance of the article is due to the problem of finding tools for the study of self-organizing processes that contribute to the promotion of social innovation. These tools are based on identifying the consequences of the activities of non-commercial entrepreneurship for the social system.

The aim of the article is to present a research approach related to the identification of development trends caused by the emergence of social innovations and their spread by non-profit public organizations in response to the emerging needs of society. 


\section{Methodological Framework}

The methodological basis of the study is based on three directions.

1. We will apply the theory of complex systems to the research of innovations that promote non-profit organizations. The beginning of the theory of complex systems (the theory of selforganization, synergetic) was put almost simultaneously by three leading scientific schools but applied to various scientific fields of knowledge. Representatives of these schools are Nobel Prize winner I. Prigozhin (see Prigozhin, 1985; Glensdorf \& Prigogine, 1973), H. Haken (1977) and S. Kurdyumov (see Kurdyumov, 1990; Kurdyumov \& Malinetskiy, 1983; Knyazeva \& Kurdyumov, 1992). The contribution of the Russian school in this scientific field is significant, especially in the area of applying synergetics to "living" systems, to the humanities of knowledge. For more than ten years, the formation of a synergistic school in the dynamic processes of the development of social systems under the guidance of Professor V. S. Yegorov. Famous scientists of the world took part in the annual seminars and conferences of 1991-2007 (see "Selforganization, Organization, Governance", 1996; "Information and Selforganization", 1997; "Synergy and Education", 1997; "Synergy and Social Governance", 1998; "Synergy and the Educational Process", 1999; "Synergy, Human, Society", 2000; "Nonlinear Dynamics and Post-Classical Science", 2003; "Strategy for the Dynamic Development of Russia: the Unity of Self-Organization and Management", 2004; Astafieva \& Riznichenko, 2007; Astafieva \& Budanov, 2009, etc.). Many famous works of scientists in the field application of synergetic to the humanitarian fields of knowledge - philosophy, psychology, sociology, political science, linguistics were created during these years, including Ye. Knyazeva and S. Kurdyumov (2002), H. Haken (see Haken \& Mikhailov, 1993), I. Prigozhin and I. Stengers (1996), V. Branskij (Branskij, 1997; Branskij, Oganyan, K. M., \& Oganyan, K. K., 2018), K. Maitser (2015), V. Arshinov and V.Budanov (2006) and others.

Non-profit organizations promoting social innovations make changes to the organizational structure of society and thereby increase the complexity of the social system as a whole. The increase in complexity is also due to the fact that the spread of innovations always combines the synthesis of two opposing processes - organization and self-organization. Self-organization is a stochastic process, in which a new order in the structure and functioning of a system is selfcreating, self-created and self-reproducing, without which it is impossible to carry out structural changes in the social system. At the same time, the new order being created must be matched with the former order parameters that ensured the vital activity of the old system, which necessitates management actions.

2. We are using the theory of evolution Development of German researchers Livehud Bernard and Fridrich Glazl (2000) for the analysis of the evolution of non-profit entrepreneurial organizations to build effective and safe interaction between organizations that are at different levels of organizational development. To do this, we introduce the following qualitative characteristics (self-identity, development strategy, structure, functions and opportunities for the distribution of powers, the degree of co-operativeness, the processes of life activity that are implemented, the types of social behavior, the attitude to managing all types of resources, the level of development 
of the leader, the risks of evolutionary development) and others (see Vasilenko \& Vronskaya, 2010).

3. The complexity of the social system, its dynamic variability structurally and qualitatively require an interdisciplinary research approach. However, "interdisciplinary scientific dialogue and relevant research cannot be conducted on the basis of the simple addition of various methodologies. These methodologies were created to solely take away their field of study from other disciplines. Lyudmila Kolesnikova argues that we cannot connect "by simple addition or merging what stands on fundamentally different fundamental principles". But it is possible, she argues, "to transform the system of basic principles into a new quality, allowing to rethink decisions and revise the system of actions. And for this, it is necessary to synthesize the initial fundamental paradigms", which suggests a method of crossdisciplinary analysis and synthesis in research involving various subject areas (see Kolesnikova, 2014, p. 14).

4. The management of the processes outlined above should take into account the trends of "natural" processes occurring in the social system, as well as the possibility of producing social risks that increase its disequilibrium. The use of the methodology of natural ordering as a scalable invariant self-similarity, coupled with an increase in entropy and the theory of fractality allows using the universal laws of the nature of the living and of the nature of the consciousness to analyze social innovations (see Kolesnikova, Vasilenko, \& Mityassova, 2017). In the modern natural science theory of the nature of living, the principle of self-organization is associated with a bifurcation of the system into a phenotype and genotype, where the information program looped into the ring with its protein product, and its enzymatic activity is aimed at preserving and reproducing the program (Galimov, 2001). The fractal approach allows us to represent the elementary unit of the created innovation construct as a phenotype and genotype. Such a construct serves as the core of an innovative fractal. The recursive cyclic repetition of this original form, by one and the same rule, at different scales, determines the universality of the mechanism of fractal ordering. Fractal self-similarity is a special recursive feedback mechanism. Fractals compactly compress information, optimally build communication channels of information and energy transfer from lower to higher levels of the hierarchy and vice versa. In the article "Applying the Fractal Concept to Research of Destructive Processes of the Methods of Clinical Sociology" (see Vasilenko, Kolesnikova, \& Pisklakova-Parker, 2012). The principle of similarity and mathematical methods help to reveal the interdependence of microscopic of behaviour and macroscopic scale, explain the hierarchy of multivariate functional systems (see Bogatyich, 2011).

\section{Conducting Research and Some Results}

The Phases of the Evolutionary Development of Nonprofit Organizations

Social fractal gradually formed in the process of the evolutionary development of the nonprofit entrepreneurial organization. At each phase of organizational development formed the specific characteristics, a part from which are fixing in the social fractal. At the core of social fractals lies unchanging basic values, spiritual principles. The tools such analysis were tested and were presented in Table 1 (see Vasilenko \& Vronskaya, 2010, p. 20). 


\begin{tabular}{|c|c|c|c|c|}
\hline $\begin{array}{c}\text { Phases of } \\
\text { development }\end{array}$ & Pioneer & Derivations & Integration & Association \\
\hline $\begin{array}{c}\text { Self-identity, } \\
\text { Values } \\
\text { Framework }\end{array}$ & $\begin{array}{l}\text { Solving specific } \\
\text { social problems. } \\
\text { Authority - the } \\
\text { basic value of the } \\
\text { head, values of em- } \\
\text { ployees - family, } \\
\text { children, health. }\end{array}$ & \begin{tabular}{|c|} 
The prevalence of \\
material and physio- \\
logical requirements \\
above spiritual and \\
ideal values. The \\
consensus of basic \\
values. Low.
\end{tabular} & \begin{tabular}{|c} 
Benefit to society. \\
Values: safety, infor- \\
mation, know-ledge. \\
Ready for re- \\
assessment of values \\
The consensus of basic \\
values average.
\end{tabular} & $\begin{array}{l}\text { The consensus of basic } \\
\text { values high. Value: life, } \\
\text { health, safety, human- } \\
\text { ism, democracy. Social, } \\
\text { informational, spiritual } \\
\text { values precedence over } \\
\text { material values. }\end{array}$ \\
\hline $\begin{array}{c}\text { Develop- } \\
\text { ment strate- } \\
\text { gy }\end{array}$ & $\begin{array}{l}\text { The idea of positive } \\
\text { society development, } \\
\text { personal knowledge } \\
\text { of the situation in } \\
\text { the management. }\end{array}$ & $\begin{array}{c}\text { Systematization, the } \\
\text { order logic, manage- } \\
\text { ability, feasibility. }\end{array}$ & $\begin{array}{c}\text { Vision objectives, } \\
\text { strategies and the } \\
\text { guidelines are generat- } \\
\text { ing by all. }\end{array}$ & $\begin{array}{l}\text { The long-term policy, } \\
\text { trust and coherence. Co- } \\
\text { operation with outside } \\
\text { social structures. }\end{array}$ \\
\hline Structure & $\begin{array}{l}\text { The personality of } \\
\text { initiator is fixing at } \\
\text { the structure, the } \\
\text { style of the work, in } \\
\text { all. }\end{array}$ & $\begin{array}{l}\text { Formal structures } \\
\text { rules, standard re- } \\
\text { quirements. }\end{array}$ & $\begin{array}{c}\text { The network of smaller, } \\
\text { relatively independent } \\
\text { structures. Business } \\
\text { network. }\end{array}$ & $\begin{array}{l}\text { Structural integration of } \\
\text { external organizations, } \\
\text { associative forms of au- } \\
\text { tonomous entities. }\end{array}$ \\
\hline $\begin{array}{l}\text { Functions, } \\
\text { the degree of } \\
\text { cooperative- } \\
\text { ness }\end{array}$ & $\begin{array}{l}\text { Functions are for- } \\
\text { ming around the } \\
\text { ability of the leaders. } \\
\text { The ability to coop- } \\
\text { eration offline. High } \\
\text { polarization. The } \\
\text { culture of power. }\end{array}$ & $\begin{array}{c}\text { Differentiation levels } \\
\text { management, con- } \\
\text { constructively, ra- } \\
\text { tionalism. Infrastruc- } \\
\text { tural cooperative. } \\
\text { The culture of the } \\
\text { tasks, The culture of } \\
\text { the roles. }\end{array}$ & $\begin{array}{c}\text { Integrated features, } \\
\text { commands, autonomous } \\
\text { groups. The accumula- } \\
\text { tion of social capital. } \\
\text { The high degree of in- } \\
\text { ternal cooperatively. } \\
\text { Development of organi- } \\
\text { zational culture, the cul- } \\
\text { ture of the individual. }\end{array}$ & $\begin{array}{l}\text { Comprehensive and sys- } \\
\text { tematic. Integrative, } \\
\text { "connecting" manage- } \\
\text { ment. The high degree } \\
\text { of internal and external } \\
\text { cooperativeness. Enter- } \\
\text { prise culture, the ability } \\
\text { to resolve conflicts. }\end{array}$ \\
\hline $\begin{array}{c}\text { The process- } \\
\text { es of vital } \\
\text { activity }\end{array}$ & $\begin{array}{l}\text { Improvisation - } \\
\text { flexibility. }\end{array}$ & \begin{tabular}{|c|} 
The requirements \\
fixed in the regulati- \\
ons and statutory re- \\
gulations. Assessment
\end{tabular} & $\begin{array}{c}\text { Needless planning. } \\
\text { Assessment of material } \\
\text { risks of the initiative } \\
\text { activities. }\end{array}$ & $\begin{array}{l}\text { Personal development } \\
\text { and mutual trust. Asses- } \\
\text { sment of material, social } \\
\text { and informational risks }\end{array}$ \\
\hline
\end{tabular}




\begin{tabular}{|c|c|c|c|c|}
\hline & & of material risks. & & the initiative activities. \\
\hline $\begin{array}{c}\text { The types of } \\
\text { social behav- } \\
\text { iour }\end{array}$ & $\begin{array}{l}\text { Interactive, entre- } \\
\text { preneurial behav- } \\
\text { iour of head, au- } \\
\text { thoritarian, charis- } \\
\text { matic, leadership. } \\
\text { Conformist behav- } \\
\text { iour in employees. } \\
\text { Dosed openness. }\end{array}$ & $\begin{array}{l}\text { Reform behaviour in } \\
\text { the head. Conformist } \\
\text { behaviour of em- } \\
\text { ployees, fixed func- } \\
\text { tions, independence } \\
\text { within the compe- } \\
\text { tence. Dosed open- } \\
\text { ness. }\end{array}$ & $\begin{array}{l}\text { Modernist behaviour of } \\
\text { employees encouraged } \\
\text { elements of entrepreneu- } \\
\text { rial behaviour in order } \\
\text { to increase the competi- } \\
\text { tiveness of the Organi- } \\
\text { zation. The open activi- } \\
\text { ties are understandable } \\
\text { for all employees. }\end{array}$ & $\begin{array}{l}\text { Transform's behaviour. } \\
\text { Transparency, open ac- } \\
\text { tivities understandable } \\
\text { for to all employees and } \\
\text { the people of the envi- } \\
\text { ronment. }\end{array}$ \\
\hline $\begin{array}{l}\text { Attitudes } \\
\text { toward the } \\
\text { use of re- } \\
\text { sources }\end{array}$ & $\begin{array}{c}\text { Means are "not im- } \\
\text { portant". }\end{array}$ & $\begin{array}{l}\text { Differentiation of } \\
\text { access to resources. } \\
\text { Responsibility, plan- } \\
\text { ning, execution, re- } \\
\text { porting and control. }\end{array}$ & $\begin{array}{l}\text { Self-organization, self- } \\
\text { control. Using the ma- } \\
\text { terial, technological } \\
\text { and information resou- } \\
\text { rces. The widespread } \\
\text { use of goodwill and } \\
\text { symbolic capital. }\end{array}$ & $\begin{array}{l}\text { Innovative entrepreneur- } \\
\text { ship, social and infor- } \\
\text { mation and knowledge } \\
\text { capitals are- develop- } \\
\text { ment resources. }\end{array}$ \\
\hline & \multicolumn{4}{|c|}{ The required level of the head, and his mind } \\
\hline & $\begin{array}{l}\text { Direct perception of } \\
\text { information; }\end{array}$ & $\begin{array}{c}\text { Orderly, analyzing, } \\
\text { comparing percep- } \\
\text { tions. The average } \\
\text { level of information- } \\
\text { al. }\end{array}$ & $\begin{array}{c}\text { Perception - Interpreta- } \\
\text { tion - Understanding } \\
\text { the value or meaning, } \\
\text { the meta-level. High } \\
\text { level of informational. }\end{array}$ & $\begin{array}{l}\text { The reflection higher } \\
\text { intelligence or wisdom. } \\
\text { High level of informa- } \\
\text { tional and morality. }\end{array}$ \\
\hline & \multicolumn{4}{|c|}{ Risks of evolutionary development and entrepreneurial activities } \\
\hline & $\begin{array}{l}\text { The chaos, arbitrar- } \\
\text { iness, lack of inde- } \\
\text { pendence of em- } \\
\text { ployees. }\end{array}$ & $\begin{array}{c}\text { Excessive formaliza- } \\
\text { tion, over organization, } \\
\text { bureaucracy. The risk } \\
\text { of criminalization, lo- } \\
\text { cal changes in the ex- } \\
\text { isting order of the pa- } \\
\text { rameters does not sup- } \\
\text { port changing rules } \\
\text { and regulations. }\end{array}$ & $\begin{array}{l}\text { The trend toward ex- } \\
\text { cessive autonomy of } \\
\text { individual divisions, } \\
\text { the struggle for auton- } \\
\text { omy. The high level of } \\
\text { opposition to the new } \\
\text { parameters of order in } \\
\text { society, the growth of } \\
\text { social tension. }\end{array}$ & $\begin{array}{l}\text { Blocks and strategic al- } \\
\text { liances usurping power } \\
\text { in the company ("state } \\
\text { within a state"). Lack of } \\
\text { coordination of entre- } \\
\text { preneurship, organiza- } \\
\text { tional and economic cul- } \\
\text { tures destroys the liveli- } \\
\text { hoods alliances. }\end{array}$ \\
\hline
\end{tabular}


The Models of Entrepreneurship in Innovation Processes

The search of "fractal channels" of the diffusion such the innovations have led us to the division of models of entrepreneurship in innovation processes on the three groups. Evaluation of systemic effects, is the basis of this division, taking into account the qualitative state of the social system. Criteria for assessing the impact of innovation are selected based on the carried functions and their impact on civil society. The quality of influence on changes in the social system is chosen as a criterion. As a result, we have identified three groups of models:

- the first group - Auto-Poesies models;

- the second group - Synergy-integrating models;

- the third group - Openness models (see Vasilenko, 2011, p. 71).

\section{Auto-Poesies Models}

The name of the group comes from the essence of the term "autopoiesis", which means a way of existence (reproduction, self-organization) of a social system, a behaviour of the system that allows it to reproduce itself and exist autonomously in a changing environment. Autopoiesis is a way for the system to reproduce itself in active interaction with the external environment, "completion of construction social worlds", a method of harmonizing social space, revising legal norms, initiating responses to emerging social fluctuations, and overcoming the destabilizing interaction of innovation participants process.

This group of models assumes local changes to the existing order parameters in the social system. A change in the behaviour of a social system under the influence of the external environment is manifested, firstly, in its desire to reproduce itself, i.e. maintain their regularities (structures, norms, decisions, values, processes), ensure their autonomy. The autonomy of the system is manifested in the fact that its regularities (structures, norms, decisions, values, processes) are born in it. The function of models - proactive adaptation of society to promote innovation in social practice.

Examples of such models are: "Coordination of Social Norms", "Reframing in Anticipatory Adaptation of Society to Promote Innovation in Social Practice", "Treatment of the Social Diseases" (see Vasilenko, L. \& Vasilenko, V., 2013, pp. 115-144). For example, a network organization of counteraction to drugs "The Union of Civil Initiatives", which unites 42 organizations. Over the years, the organization has helped more than 55 thousand people. More than 28 thousand people completed a course of rehabilitation and returned to normal life! All people rehabilitated free of charge and regardless of nationality, place of residence, religion. "The Union of Civil Initiatives" created the official standard of its services to rehabilitation of persons suffering from drug addiction. They held an extensive discussion and public examination of this standard and then filed an application for approval of the standard to the Federal Agency for technical regulation and metrology has issued a certificate of registration. December 12, 2012, the "The System of Voluntary Certification of Rehabilitation Services to Persons Dependent on Narcotic Resources, Psychotropic Substances and Alcohol". This work allowed to improve their services and helps to protect from biased control over their activities from the authorities. 
Synergy-Integrating Models

Synergy-integration models of entrepreneurship are associated with the growing complexity of social systems. The basis of this group of models is the formation of the ability of the combining parts of the future complex system to achieve the effect of synergy or save it from external influences. They predetermine the search for ways to accelerate evolution, the application of the laws of combining complex social structures through the birth of new social connections, co-evolution, and the harmonization of development rhythms in the social system.

We are talking about how to coherently and consistently to act together, how to destroy outdated social relations. Methods of achievement are determined forming relationships, the quality of interactions, the conditions and principles of uniting social communities into a common complex system, which is a qualitatively new fortune.

Examples of such models: "Cluster's Cooperation", "Integration", "Corporate Citizenship and Social Responsibility", "Self-Regulation the Form of Integration Processes" (see Vasilenko, L. \& Vasilenko, V., 2013, pp. 160-240).

For example, one of the forms of transfer of authority from the authorities is the transfer of control and supervisory functions of the state over the activities of subjects in a particular area to the market participants themselves through a self-regulation mechanism. The implementation of the self-regulation mechanism is carried out through the development of rules and standards for professional activity and business ethics and the practice of relations among themselves, with clients and with the authorities; ensuring proper control by professional associations over the ac- tivities of their members, including sanctions for their violation; representing the interests of participants in self-regulatory organizations before third parties, including out-of-court settlement of disputes between members of an association and between members of self-regulating organizations and consumers. Instead of state licensing of a huge list of types of professional activity, collective regulation of stakeholders in a particular area is carried out. In case of non-compliance with the rules, sanctions can be applied to the violator, both by the state and non-state actors in the process of self-regulation. Entrepreneurs themselves determine the "rules of the game" in the market, exercising control through elected collegial bodies.

\section{Openness Entrepreneurship Models}

The group of opening models defines the processes of opening social systems for the future. Their use makes it possible to realize the potential possibility of the emergence of fundamentally new order parameters, a new fragment of a social system, as well as a radical modernization or destruction of the order parameters of the old social system, hindering its development. The basis of opening models lies in the ability of society to adjust the basic principles, values, the system of rules by which it lives, in connection with the world changed and our ideas about it. The key element of the global and universal evolutionary process is man, and the degree of openness of society is directly related to the information development of man and his social activity.

The use of modern marketing technologies in the conditions of an innovative information environment requires, firstly, the development of 
effective communications, and secondly, a combination of various ways of presenting contagious, memorable means of presenting innovations, applying all the possibilities of social marketing - sampling (design of innovation), reframing (the conclusions of the appeared sample in the new frame) and branding (the formation in future consumers of the adoption of innovations images, that have the desired properties and characteristics) in order to stimulate the social epidemic for innovation.

Openness entrepreneurship models include the processes of nucleation of new order parameters of the social system, modernization of old order parameters or their destruction. Examples of such models: "Birth Order Parameters", "Reducing the Resistance to Social Change", "Social Investment" (see Vasilenko, L. \& Vasilenko, V., 2013, pp. 257-262).

For example, the national network against violence "ANNA", uniting more than one hundred non-profit and governmental organizations from Russia and countries of post-Soviet space. In the process of the internship, pursued by ANNA for the representatives of the Russian public and state organizations (crisis centers, courts, law enforcement bodies, social workers of municipalities, etc.), working with the domestic violence problem, have mastered knowledge and skills that help to increase the effectiveness of their practical work. The result - "Standards of service activities to victims of domestic violence" and the draft law "On prevention and prevention of domestic violence" and the public examination of this bill. The bill discussed on the public and parliamentary debates. The Presidential Council on Civil Society and Human Rights gave a ruling "On the pre-Prevention and prevention of domestic violence" and handed him to the
President of Russian Federation V. V. Putin. The draft this federal law aims to create a legal mechanism for implementing economic, social and political measures to combat and prevention with violence in the family and domestic sphere.

\section{Conclusion}

We think about the new entrepreneur like a man of the future (Homo Divinans), which has a high level of consciousness and morality, informational openness, the creative thinking, the ability to find a consensus of basic values to build these models. We have identified the tendency of formation of such individuals in the sociological studies of NPO "SOCINCO" (see Vasilenko, V., Vasilenko, L., Kazantseva, \& Tarasova, 2015). We research the interactive dialogue between power and citizens. On this basis, we created 16 models of the interactive dialogues and written the handbook for authorities and non-profit organizations on.

In summary, we note that the fractalsynergetic approach to the study of entrepreneurship in the non-profit organizations allows us to consider innovative behaviours of citizens in the dynamically developing democratic society.

\section{REFERENCES}

Arshinov, V. I., \& Budanov, V. G. (2006). Sinergetika na rubezhe XX - XXI vekov (Synergetics at the Turn of the XX XXI Centuries, in Russian) (A. I. Panchenko, Ed.). Moscow: INION RAN.

Astafieva, O. N., \& Budanov V. G. (Eds.). (2009). Sinergeticheskaya paradigma. Social'naya sinergetika (Synergetic Paradigm. Social Synergy, in Russian). 
Moscow: Progress-Tradition.

Astafieva, O. N., \& Riznichenko, G. Yu. (Eds.). (2007). Sinergeticheskaya paradigma. Sinergetika obrazovaniya (Synergetic Paradigm. Synergetics of Education, in Russian). Institute of Philosophy of the Russian Academy of Sciences. Moscow: Progress-Tradition.

Bogatyich, B. A., (2011). Fraktal'naya priroda zhivogo: sistemnoe issledovanie biologicheskoi evolyutsii i prirody soznaniya (The Fractal Nature of the Living: a Systematic Study of the Biological Evolution and Nature of Consciousness, in Russian). Moscow: URSS.

Branskij, V. P., (1997). Teoreticheskie osnovaniya sotsial'noi sinergetiki (Theoretical Foundations of Social Synergetics, in Russian). Petersburg Sociology, 1, 154156.

Branskij, V., Oganyan, K. M., \& Oganyan, K. K. (2018). A New Line of Research: Synergetic Philosophy and Sociology of Personality. WISDOM, 1(10), 57-72. doi:10.24234/wisdom.v10i1.203.

Galimov, E. M., (2001). Fenomen zhizni: mezhdu ravnovesiem $i$ nelineinost'yu. Proiskhozhdenie $i$ printsipy evolyucii (The Phenomenon of Life: between Equilibrium and Nonlinearity. The Origin and Principles of Evolution, in Russian). Moscow: Editorial URSS.

Glensdorf, P., \& Prigogine, I. (1973). Termodinamicheskaya teoriya struktury, ustoichivosti i fluktuacii (Thermodynamic Theory of Structure, Stability, and Fluctuations, in Russian). Moscow: Mir.

Haken, H. (1977). Synergetics. Berlin: SpringerVerlag.
Haken, H., \& Mikhailov, A. (Eds.) (1993). Interdisciplinary Approaches to Nonlinear Complex Systems. Berlin: Springer.

Informatsiya $i$ samoorganizatsiya (Information and Selforganization, in Russian). (1997). Moscow: RAGS.

Knyazeva, E., \& Kurdyumov, S., (1992). Sinergetika kak novoe mirovidenie: dialog $s$ I. Prigozhinym (Synergetics as a New Worldview: Dialogue with I. Prigozhin, in Russian). Issues of Philosophy, 12, 320.

Knyazeva, Ye., \& Kurdyumov, S. P. (2002). Osnovaniya sinergetiki Rezhimi s obostreniem, samoorganizhatsiya, Tempomiry (Grounds of Synergetics. Regime with aggravation, Self-Organization, Tempo-Worlds, in Russian). Saint Petersburg: Aletheia.

Kolesnikova, L. A., (2014). Revolyuciya fraktal'nogo kross-distsiplinarnogo sinteza ili estestvennye nachala $i$ voprosy metodologii mezhdistsiplinarnogo dialoga $v$ social'nykh i gumanitarnykh naukakh (Revolution Fractal Cross-Disciplinary Synthesis or Natural Beginning and Methodological Issues of Interdisciplinary Dialogue in the Social Sciences and Humanities, in Russian). In N. E. Pokrovsky (Ed.), Sociology. Natural. Society: Collection of Scientific Articles, and Materials of the All-Russian Scientific Conference "Sociology and Nature of Knowledge: Interdisciplinary Approaches to the Study of Social Reality". December 12-13, 2014, Moscow (pp. 13-18). Moscow: ROO "Soobschestvo professionalnikh sotsiologov", OOO "Variant". 
Kolesnikova, L. A., Vasilenko, L. A., \& Mityassova, E. A. (2017). Tonkaya koordinatsiya vs gibridnaya gegemoniya: faktor dukhovnosti v otnosheniyakh territorii s pozitsii fraktal'nogo kross-distsiplinarnogo sinteza (Fine-Tuning Coordination vs Hybrid Hegemony: a Factor of Spirituality in Relations of Territories from the Viewpoint of Fractal CrossDisciplinary Synthesis, in Russian). In L. A. Vasilenko (Ed), Socio-Cultural Aspect of Eurasian Integration. Eurasian Civic Alliance: Collection of Articles of the International Scientific Conference (395-420). Belgorod: "Belgorod" NIU "BelGU".

Kurdyumov, S. \& Malinetskiy, G. (1983). Sinergetika - teoriya samoorganizatsii. Idei, metody, perspektivy (Synergetics - the Theory of Self-Organization. Ideas, Methods, Perspectives, in Russian). Moscow: Znanie.

Kurdyumov, S. M., (1990). Evolution and SelfOrganization Laws in Complex Systems. International Journal of Modern Physics, C1, 299-327.

Livehud, B., \& Glazl, F., (2000). Dinamichnoe razvitie predpriyatiya. Kak predpriyatiya-pionery i byurokratiya mogut stat' effektivnymi (The Dynamic Development of the Enterprise. As Pioneers of the Enterprise and the Bureaucracy Can be Effective, in Russian). Kaluga: Spiritual knowledge.

Maitser, K., (2015). Issleduya slozhnost': ot iskusstvennoi zhizni i iskusstvennogo intellekta $k$ kiberfizicheskim sistemam (Studying the Complexity: from an Artificial Life and an Artificial Intelli- gence to Cyberphysical Systems, in Russian). Moscow. Knizhnyi dom "LIBROKOM".

Nelineinaya dinamika $i$ postneklassicheskaya nauka (Nonlinear Dynamics and PostClassical Science, in Russian). (2003). Moscow: RAGS.

Prigozhin, I. \& Stengers, I. (1996). Poryadok iz khaosa. Novyi dialog cheloveka s prirodoi (Order from Chaos. New Dialogue of the Person with the Nature, in Russian). Moscow: Progress.

Prigozhin, I. (1985). Ot sushchestvuyushchego $k$ voznikayushchemu: Vremya $i$ slozhnost'v fizicheskikh naukakh (From Existing to Arising: Time and Complexity in the Physical Sciences, in Russian). Moscow: Nauka.

Samoorganizatsiya, organizatsiya, upravlenie (Selforganization, Organization, Governance, in Russian). (1996). Moscow: RAGS.

Sinergetika i obrazovanie (Synergy and Education, in Russian). (1997). Moscow: RAGS.

Sinergetika i social'noe upravlenie (Synergy and Social Governance, in Russian). (1998). Moscow: RAGS.

Sinergetika $i$ uchebnyi process (Synergy and the Educational Process, in Russian). (1999). Moscow: RAGS.

Sinergetika, chelovek, obshchestvo (Synergy, Human, Society, in Russian). (2000). Moscow: RAGS.

Strategiya dinamicheskogo razvitiya Rossii: edinstvo samoorganizacii i upravleniya (Strategy for the Dynamic Development of Russia: the Unity of SelfOrganization and Management, in Rus- 
sian). (2004). Moscow: Prospect.

Vasilenko, L. A. (2011). Menedzhment social'nykh innovacii: upravlenie budushchim (Management of Social Innovation: Managing the Future, in Russian). Civil Service, 3(71), 70-74.

Vasilenko, L. A., \& Kolesnikova, L. A. (2015). Nauchnaya racional'nost' $v$ social'nom poznanii (Scientific Rationality in Social Cognition in Russian). The Economic and Socio-Humanitarian Studies, 3(7), 81-93.

Vasilenko, L. A., \& Vasilenko, V. I. (2013). Sotsial'nye innovatsii $v$ contekste upravleniya budushchim (Social Innovations in the Context of Management of the Future, in Russian). Mahachkala: Raduga.

Vasilenko, L. A., Kolesnikova, L. A., \& Pisklakova-Parker, M. P. (2012). Primenenie koncepcii fraktal'nosti $k$ issledovani- yam destruktivnykh processov metodami klinicheskoi sociologii (Applying the Fractal Concept to Research of Destructive Processes of the Methods of Clinical Sociology, in Russian). Human Capital, 9, 62-67.

Vasilenko, L. A., Vasilenko, V. I., Kazantseva, O. A., \& Tarasova, E. V. (2015). Modeli dialoga vlasti $i$ obshchestva $v$ internet-kommunikatsiyakh (Models of Dialogue between the Authorities and Society in Internet Communications, in Russian). Moscow: Prospect.

Vasilenko, L. A., \& Vronskaya, M. I. (2010). Vzaimodeystvie organov gosudarstvennoi vlasti i mestnogo samoupravlenia s institutami grazhdanskogo obshchestva (Interaction of Bodies of State Power and Local Self-Government with Institutions of Civil Society, in Russian). Moscow: Prospect. 